\title{
Ancoragens de tubulações com junta elástica
}

\section{Ibrahim Lasmar}

Este livro supre a falta de publicações técnicas que abordem de forma profissional e sem superficialidades todos os tipos e casos de ancoragens de tubulações com junta elástica, com recomendações e métodos de cálculo e projeto.

Pode-se dizer que mais de $50 \%$ dos acidentes e colapsos dessas tubulações são devido às falhas de ancoragem.

Portanto, trata-se de assunto de extrema importância, tanto no projeto como na execução de obras hidráulicas com tubulações sob pressão.

A obra reflete e registra a experiência do autor e da equipe com quem trabalhou por longos anos, incluindo a narrativa de casos de acidentes.

Ibrahim Lasmar, Engenheiro Civil e Sanitarista, formado pela Escola Nacional de Engenharia da Universidade do Brasil (atual Universidade Federal do Rio de Janeiro) em 1951, iniciou suas atividades profissionais em 1952 na Comissão de Águas e Engenharia Sanitária do antigo Estado do Rio de Janeiro onde, até 1969, exerceu as funções de Engenheiro projetista, Chefe da Seção de Projetos e Diretor Técnico. A partir daí, atuou em importantes empresas de consultoria, construção e montagem, atuando no

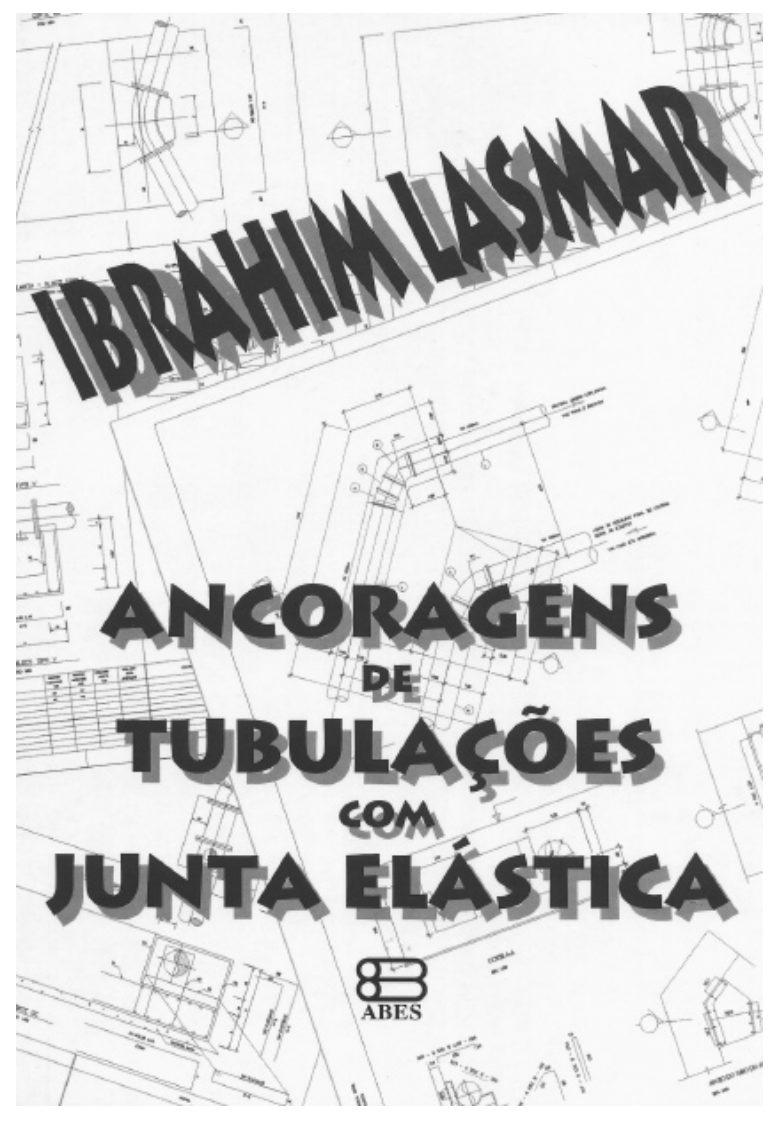
projeto de mais de $1.200 \mathrm{~km}$ de tubulações condutoras de água sob pressão, nos mais variados diâmetros, extensões e pressões.

O autor também foi professor de Física na Universidade Federal Fluminense, durante mais de 40 anos, e de Abastecimento de Água na Escola Nacional de Engenharia nos idos de 1960, além de ter sido "professor" de todos aqueles que com ele trabalharam, tanto nos aspectos técnicos quanto humanos.

Sua didática e seu trato simples das coisas sempre causaram admiração nos que tiveram o privilégio de conviver com ele, e estão presentes neste livro, o que o torna de fácil leitura e uso.

Com 132 páginas, é dividido em 11 capítulos muito bem organizados e que esgotam o assunto:

1. Critérios e Parâmetros de Cálculo

2. Esforços Solicitantes

3. Esforços Resistentes

4. Outros Esforços

5. Condições de Equilíbrio

6. Ancoragens Especiais

7. Tubos Soldados e Flangeados

8. Exemplos de Cálculo

9. Documentação Fotográfica (a cores) 10. Recomendações para Projetos de Adutoras

11. Acidentes Ocorridos ou Evitados

Ibrahim Lasmar foi um engenheiro e uma pessoa extraordinária. Deixou-nos recentemente, mas antes, tomou o cuidado de nos legar, por meio deste livro, o que aprendeu. Assim, os que vierem depois já podem começar desse patamar.

É um livro necessário e essencial em qualquer biblioteca do ramo. Vale a pena tê-lo.

\section{Comentário elaborado por Miguel Fernández y Fernández Coordenador da coluna Livros: Cícero Onofre de Andrade Neto}

A sessão "Livros", que a cada edição traz resumos comentados sobre livros de interesse na área, tem como principal objetivo permitir que o leitor, de forma rápida, se atualize e conheça o que há disponível no mercado editorial. As contribuições deverão ser encaminhadas para: resa@abes-dn.org.br 